\title{
Effects of a Novel Fermented Soy Product on the Serum Lipids of Hypercholesterolemic Rabbits
}

\author{
Elizeu A. Rossi, Regina C. Vendramini, Iracilda Z. Carlos, Igor S. Ueiii, Márcio M. Squinzari, \\ Sinézio I. Silva Jr, Graciela F. Valdez
}

Araraquara, SP - Brazil

\begin{abstract}
Objective - To assess the effect of a new feed soy product fermented by Enterococcus faecium and Lactobacillus jugurti on the serum lipid levels of rabbits with induced hypercholesterolemia.
\end{abstract}

Methods - Thirty-two rabbits were divided into 4 groups as follows: 1) control (C);2) hypercholesterolemic $(H) ; 3)$ hypercholesterolemic + fermented product $(H P F)$; and 4) control + fermented product $(C P F)$. The $H$ and $H P F$ groups were fed with a diet with $0.15 \%(p / p)$ cholesterol in the first 15 days. $C$ and $C P F$ groups received regularfood preparation. The HPF and CPF groups received $10 \mathrm{~mL}$ daily of the fermented 30 days. Blood samples were drawn at the beginning of the study and at the $15^{\text {th }}$ and $30^{\text {th }}$ days. Concentrations of total cholesterol, $H D L$ cholesterol, and triglycerides were analyzed.

Results - After 15 days, the HPF group showed a total cholesterol concentration lower (18.4\%) than that of the H group ( $p=0.05)$, but this difference disappeared after 30 days. No change was observed in total cholesterol levels of $C$ and $C P F$ groups. After 15 days, the HDLcholesterol was higher (17.8\%) in the HPF group, but the triglyceride levels remained unchanged in all groups during the same period of time.

Conclusion - The soy fermented product caused an $18.4 \%$ reduction in total cholesterol and a $17.8 \%$ increase in the HDL-fraction. It may, therefore, be a possible coadjutor in the treatment of hypercholesterolemia.

Key words: fermented soy product, Enterococcus faecium, cholesterol

Faculdade de Ciências Farmacêuticas de Araraquara-UNESP

Mailing address: Elizeu A. Rossi - Faculdade de Ciências Farmacêuticas de Araraquara-UNESP - Rod. Araraquara-Jaú, Km 01, Campus Universitário 14801-902 - Araraquara, SP, Brazil
Hypercholesterolemia is a significant risk factor in the development of heart diseases, which are one of the major causes of death in Western countries.

A report of the Lipid Research Clinics shows that a reduction in the serum cholesterol level helps to decrease the incidence of deaths due to coronary artery disease in populations with diets rich in lipids ${ }^{1}$. Therefore, aiming to develop a hypocholesterolemic action, several studies have been carried out in the medicamentous area and, more recently, in the food area.

The so-called functional foods, those that have prophylactic or therapeutical properties, or both, have been widely researched aiming to provide the population with alternative ways of prevention and combat of certain diseases ${ }^{2-6}$.

In regard to the specific reduction in cholesterol, several studies have been carried out with products fermented by lactic bacteria, which may account for the observed effects ${ }^{7-9}$. However, most of these studies were performed with Lactobacillus acidophilus, and much data about other bacteria that could have similar effects do not exist.

Rossi et $\mathrm{l}^{10}$ carried out an in vitro study about the ability of Enterococcus faecium, which are microorganisms widely encountered inside the human bowel, to reduce cholesterol. These authors observed a 53.85\% reduction in the cholesterol added to the culture medium of this bacterium. This result led the researchers to develop a soy product fermented by the E. faecium with technological and sensorial properties very similar to those of the conventional fermented products ${ }^{11}$. Its eventual hypocholesterolemic effect, however, was not demonstrated in vivo.

Therefore, the present study aims to demonstrate in laboratory animals (rabbits with hypercholesterolemia induced by the lipid-rich diet) the effect resulting from the daily ingestion of the soy product fermented by E. faecium and $L$. jugurti on the serum lipid levels (total cholesterol, HDLcholesterol, and triglycerides).

\section{Methods}

Thirty-two male rabbits of the New Zealand variety 
with 8 weeks of age were used in the study. They were kept in individual cages in a vivarium with controlled temperature $\left(23 \pm 2^{\circ} \mathrm{C}\right)$ and automatic control of light-dark/12 hours.

Before beginning the experiment, the animals went through a period of flavor conditioning, when they first received the sweet solution, then the sweet and acid solution, and finally the placebo product.

The animals were randomly divided into 4 groups $(n=8)$ as follows: the hypercholesterolemic group $(\mathrm{H})$; the hypercholesterolemic + fermented product group (HPF); the control group $(\mathrm{C})$; and the control + fermented product group (CPF).

All groups were fed with commercial food preparation for rabbits (Purina ${ }^{\circledR}$ ), and the animals of the H and HPF groups received in the first 15 days of the study an addition of $0.15 \%$ (p/p) of Sigma C 8503 cholesterol to their food preparation. This cholesterol was diluted in ethyl ether P.A. and stabilized with 10 ppm of butylated hydroxytolueneBHT. The HPF and CPF groups received daily $10 \mathrm{~mL}$ of the fermented product (the dose was established in prior trials) during the 30 days of the study. Ingestion of food preparation was controlled for all groups during the study.

The fermented product was prepared according to the methodology described by Rossi et al ${ }^{12}$, except for the replacement of the inoculum for $1.5 \%$ (v/v) of the Enterococcus faecium CRL 183 culture and $1.5 \%(\mathrm{v} / \mathrm{v})$ of the Lactobacillus jugurti 416 culture.

Quantification of the viable cells in the finished fermented product, was performed using the specific M 17-agar and MRS-agar media of culture. The colonies formed were counted and their morphological characteristics were recorded.

Blood samples were drawn from the arteries of the ears at the beginning of the experiment (basal measurement), and at the $15^{\text {th }}$ and $30^{\text {th }}$ days.

Measurements of total cholesterol, HDL-cholesterol, and triglycerides were performed through specific enzymatic kits as follows: to determine total cholesterol, the fastcolor cholesterol method was employed ${ }^{13,14}$, with reagents from the Sera Pak-Ames-Analyzer RAXT-TechniconAmes; triglycerides were determined through the fast-color triglyceride method ${ }^{15}$, with reagents from the same Sera Pak-Ames-Analyzer RAXT-Technicon-Ames; to determine the HDL-cholesterol level, a selective precipitation of lipoproteins was first required according to the methodology of Bergmeyer ${ }^{16}$ and then the HDL-cholesterol level was determined in the skim employing the methodology used for total cholesterol.

All data obtained underwent the one-way analysis of variance (ANOVA) and the Tukey test for comparison of the means.

Statistical analyses were performed using SAS (Statistical Analysis System) ${ }^{17}$.

\section{Results}

Values of the serum lipids assessed during the study are shown in table I.

\begin{tabular}{|c|c|c|c|}
\hline & Basal & 15 Days & 30 Days \\
\hline \multicolumn{4}{|c|}{ Total cholesterol } \\
\hline $\mathrm{H}$ & $51.0 \pm 7.6^{\mathrm{a}}$ & $232.8 \pm 49.7^{\mathrm{a}}$ & $69.0 \pm 25.8^{\mathrm{a}}$ \\
\hline $\mathrm{C}$ & $40.3 \pm 1.6^{\mathrm{b}}$ & $35.8 \pm 2.1^{\mathrm{c}}$ & $36.2 \pm 2.5^{\mathrm{b}}$ \\
\hline $\mathrm{CPF}$ & $39.8 \pm 2.4^{b}$ & $37.2 \pm 2.9^{c}$ & $38.3 \pm 3.7^{b}$ \\
\hline HPF & $54.0 \pm 1.3^{\mathrm{a}}$ & $190.0 \pm 44.8^{\mathrm{b}}$ & $48.0 \pm 6.7^{\mathrm{a}, \mathrm{b}}$ \\
\hline \multicolumn{4}{|c|}{ HDL-cholesterol } \\
\hline $\mathrm{H}$ & $29.0 \pm 5.8^{\mathrm{a}}$ & $28.0 \pm 3.1^{\mathrm{b}}$ & $32.2 \pm 4.9^{\mathrm{a}}$ \\
\hline $\mathrm{C}$ & $26.0 \pm 3.1^{\mathrm{a}}$ & $20.8 \pm 1.5^{\mathrm{c}}$ & $22.3 \pm 2.1^{\mathrm{b}}$ \\
\hline $\mathrm{CPF}$ & $25.0 \pm 2.9^{\mathrm{a}}$ & $21.8 \pm 1.6^{c}$ & $21.0 \pm 1.6^{\mathrm{b}}$ \\
\hline HPF & $27.0 \pm 2.5^{\mathrm{a}}$ & $33.0 \pm 3.0^{\mathrm{a}}$ & $31.0 \pm 5.7^{\mathrm{a}}$ \\
\hline \multicolumn{4}{|c|}{ Triglycerides } \\
\hline $\mathrm{H}$ & $95.0 \pm 15.2^{\mathrm{a}}$ & $84.0 \pm 27.8^{\mathrm{a}}$ & $74.0 \pm 13.0^{\mathrm{b}}$ \\
\hline $\mathrm{C}$ & $102.8 \pm 21.4^{\mathrm{a}}$ & $103.3 \pm 8.2^{\mathrm{a}}$ & $110.0 \pm 17.6^{\mathrm{a}}$ \\
\hline $\mathrm{CPF}$ & $110.8 \pm 22.7^{\mathrm{a}}$ & $105.3 \pm 11.0^{\mathrm{a}}$ & $106.2 \pm 7.0^{\mathrm{a}}$ \\
\hline HPF & $128.0 \pm 29.3^{\mathrm{a}}$ & $109.0 \pm 26.3^{\mathrm{a}}$ & $92.0 \pm 5.1^{\mathrm{a}, \mathrm{b}}$ \\
\hline \multicolumn{4}{|c|}{$\begin{array}{l}\text { Mean values expressed in } \mathrm{mg} / \mathrm{dL} \text { (mean } \pm \text { standard deviation) } \\
\mathrm{H} \text { - hypercholesterolemic group; C- control group; CPF- control }+ \\
\text { fermented product group; HPF- hypercholesterolemic }+ \text { fermented } \\
\text { product group. Statistical comparison between groups: values with } \\
\text { different letters differ significantly between themselves }(\mathrm{p} \leq 0.05 \text { ). }\end{array}$} \\
\hline
\end{tabular}

The HPF group showed at the end of the $15^{\text {th }}$ day a mean level of total cholesterol significantly lower than that observed in the $\mathrm{H}$ group ( $\mathrm{p}=0.05$ ).

When cholesterol was withdrawn from the diet of the animals in the Hand HPF groups in the last 15 days of the experiment, the levels of total cholesterol did not show a significant difference between the two groups. In the $\mathrm{C}$ and $\mathrm{CPF}$ groups, the total cholesterol levels did not show any significant differences at the $15^{\text {th }}$ and $30^{\text {th }}$ days of the experiment.

In regard to the levels of HDL-cholesterol at the $15^{\text {th }}$ day, the $\mathrm{H}$ group showed a mean value lower than that of the HPF group ( $\mathrm{p} \leq 0.05)$, however by the $30^{\text {th }}$ day, these groups showed no difference. The $\mathrm{C}$ and CPF groups showed no differences during all the study in regard to HDL-cholesterol levels.

The mean values of triglycerides are also shown in table I. All four groups showed no significant differences in the triglyceride levels in the basal measurement and at the $15^{\text {th }}$ day of the experiment. Only by the end of the $30^{\text {th }}$ day, the $\mathrm{H}$ group showed a value significantly lower than those observed in the $\mathrm{C}$ and CPF groups ( $\mathrm{p}=0.05)$, whose values did not differ between them.

There was no significant difference in the food intake by the animals of the groups during the first 15 days of the study, a period in which the animals in the $\mathrm{H}$ and HPF groups ingested food preparation with cholesterol (fig. 1).

The fermented product administered to the animals underwent a counting of viable cells (cocci and bacilli). The results showed that all lots of the fermented product had cells of both bacterial genders at the level of $10^{8} \mathrm{ufc} / \mathrm{mL}$ (table II).

\section{Discussion}

After 15 days, the intake of $0.15 \%$ (p/p) of cholesterol in the diet caused a significant increase of the total choleste- 


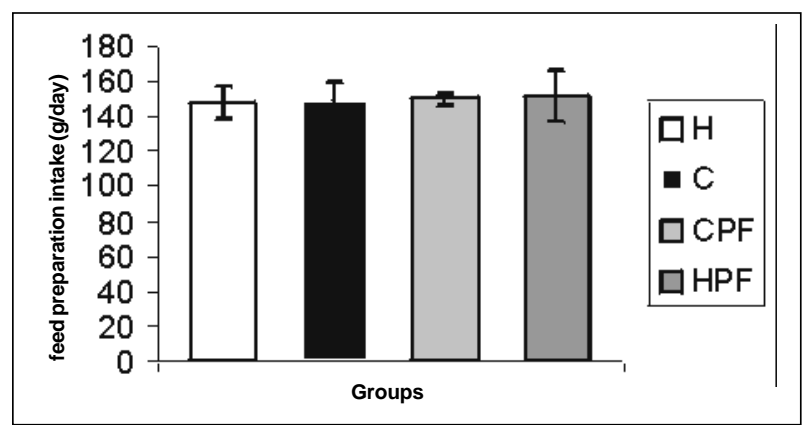

Fig. 1 - Means values and standard deviation of feed consumption. $\mathrm{H}$ - Hypocholesterolemic group; C - Control group; CPF - Control + fermented product group; HPF - Hypercholesterolemic + fermented product group.

\begin{tabular}{|cccc|}
\hline \multicolumn{4}{|c|}{ Table II - Number of viable cells in different lots of the fermented } \\
soy product administered to the animals & \\
\hline $\begin{array}{l}\text { Lot of } \\
\text { product }\end{array}$ & $\begin{array}{c}\text { Cocci } \\
\text { (ufc/ml) }\end{array}$ & $\begin{array}{c}\text { Bacilli } \\
(\mathrm{ufc} / \mathrm{ml})\end{array}$ & $\begin{array}{c}\text { Gram } \\
\text { stain }\end{array}$ \\
\hline 001 & $13.0 \times 10^{8}$ & $16.0 \times 10^{8}$ & + \\
002 & $12.0 \times 10^{8}$ & $14.0 \times 10^{8}$ & + \\
003 & $13.0 \times 10^{8}$ & $17.0 \times 10^{8}$ & + \\
\hline
\end{tabular}

rol in the animals that had not ingested the fermented product ( $\mathrm{H}$ group) as compared with those receiving a daily dose of $10 \mathrm{~mL}$ of the fermented product (HPF group). This shows that the product being studied caused an $18.4 \%$ reduction in the concentration of total cholesterol. This difference disappeared at the $30^{\text {th }}$ day showing that the fermented soy product did not cause a more rapid decrease in the total cholesterol level when cholesterol was eliminated from the $\operatorname{diet}$ (the last 15 days of the experiment).

A reduction in total cholesterol observed with the use of the fermented product was expected because previous studies ${ }^{10}$ performed in vitro showed the ability of the $E$. faecium (the bacterium used in the fermentation of the product studied) to reduce in 54\% the cholesterol added to the adequate culture medium.

The animals in the $\mathrm{C}$ and $\mathrm{CPF}$ groups, which did not receive cholesterol in the diet, did not show a significant difference in the values of total cholesterol during the entire period studied. These results are interesting as they indicate that a reduction in the total cholesterol level observed in the HPF group due to the use of the fermented product oc- curs in the cholesterol originating from the food. It seems that the fermented product does not interfere with the synthesis of the endogenous cholesterol. This evidence emphasizes the mechanism proposed by Klaver and Meer ${ }^{18}$ to explain the reduction in the cholesterol levels by lactic bacteria. According to those authors, this reduction results from precipitation of the cholesterol inside the bowel with a consequent decrease in its absorption due to the disconjugating activity of the bile salts caused by certain lactic bacteria that, through the fermented product, reach the intestines and remain there.

It is worth emphasizing that the difference in the total cholesterol levels observed between the H and HPF groups cannot be attributed to differences in cholesterol ingestion in the diet because the feed intake in all groups showed no significant difference between them.

The $17.8 \%$ increase in the HDL-fraction observed by the $15^{\text {th }}$ day in the animals receiving a diet with cholesterol and the fermented product (HPF group) as compared with those that received the diet with cholesterol but no fermented soy product (H group) is one more indication of the beneficial effect of the product. The increase in this cholesterol fraction is one of the factors determining a reduction in the risk of cardiovascular diseases ${ }^{19}$.

Similar results were obtained by Fukushima and Naka$\mathrm{no}^{20}$, who showed that rats fed with a diet rich in cholesterol had a reduction in the total cholesterol and an increase in the HDL fraction with a daily intake of a probiotic product containing several species of Lactobacillus, Streptococcus, and yeast.

In conclusion, the results observed in this study show that the soy product fermented by E. faecium and L. jugurti managed to cause an $18.4 \%$ reduction in the serum level of total cholesterol and a $17.8 \%$ increase in the level of the HDLfraction. Therefore, this fermented soy product may represent a possible aid in the treatment of hypercholesterolemia.

\section{Acknowledgments}

We would like to thank the Fundação de Amparo à Pesquisa do Estado de São Paulo (FAPESP), the Centro Argentino-Brasileiro de Biotecnologia (CABBIO/CNPq), and the Programa de Apoio ao Desenvolvimento Científico (PADC/ FCF-UNESP) for the financial support. We would also like to thank Mrs. Roseli Ap. Pinto for technical support.

\section{References}

1. Havernaar R, Brink B, Ved J. Selection of strains for probiotic use. In: Probiotics the Scientific Basis. Ed. London: Chapman and Hall, 1992: 209.

2. Arai S. Studies on funcional foods in Japan-State of the art. Biosci Biotech Biochem 1996; 60: 9-15.

3. Byrne M. Nutraceuticals: food fad on future trend. Food Engine Intl 1994; 19: 42-3.

4. Haumann BF. Designing foods - Manipulating foods to promote health. Inform 1993; 4: 344-56.

5. Pszczola DE. Designer foods: An envolving concept. Food technol 1993; 47: 92.
6. Tuley L. Funcional foods-the technical issues. Food manufacture 1995; 70: 30-2.

7. Mann GV. A factor in yogurth wich lowers cholestrolemia in man. Atheroscl 1977; 26: 335-40.

8. Grunewald KK. Serum cholesterol levels in rats fed skin milk fermented by Lactobacillus acidophilus. J Food Sci 1982; 47: 2078-9.

9. Gilliland SE, Nelsen CR, Maxwell C. Assimilation of cholesterol by Lactobacillus acidophilus. Apllied Envirom Microbiol 1985; 49: 277-81. 
10. Rossi EA, Giori GS, Holgado APR, Valdez GF. In vitro effect of Enterococcus fae cium and Lactobacillus acidophilus. Microbiol Alim Nutr 1994; 12: 267-70.

11. Rossi EA, Vendramini RC,Valdez GF. Development of a novel fermented soy milk product with potencial probiotic properties. Eur Food Res Technol 1999; 209: 305-7.

12. Rossi EA, Reddy KV, Silva RSSF. Formulation of soy whey yogurt using response surface methodology. Arq Biol Tecnol 1984; 27: 387-90.

13. Association of Official Analytical Chemists. Official Methods of Analysis. Maryland, 1997; 2: 16

14. Allain CA, Poon LS, Chan CSG, Richmond W, Fu PC. Enzymatic determination of total serum cholesterol. Clin Chem 1974; 20: 470-5.

15. Fossati P, Prencipe L. Serum triglycerides determined colorimetrically with an enziyme that procedure hydrogen peroxide. Clin Chem 1982; 28 : 2077-80.

16. Bergmeyer HW. Methods of Enzimatic Analysis. $2^{\text {nd }}$ ed.. 1974; 4: 1890-3.

17. SAS (Statistical Analysis System) Institute. SAS/TAT User's Guide. $4^{\text {th }}$ ed., Version 6, 1990; 1.

18. Klaver FAM, Meer R. The assumed assimilation of cholesterol by Lactobacilli and Bifidobacterium is due to their bile salt desconjugating activity. Applied Envirom Microbiol 1993; 59: 1120-4

19. Rackley CE. Hypercholesterolemia. Drugs of today 1997; 33: 307-14.

20. Fukushima M, Nakano M. The effect of a probiotic on faecal and liver lipid classes in rats. British J Nutr 1995; 73: 701-10. 